\title{
Recurso de áto do Interventor Federal para o sr. Presidente da República
}

Ernesto Leme

\author{
PARECER
}

1 - O decreto federal n. 19.398, de 11 de novembro de 1930, que instituiu o governo provisório da República, assim dispôs, em seu art. 11: “O governo provisório nomeará um interventor federal para cada Estado, salvo para aqueles já organizados, em os quais ficarão os respetivos presidentes investidos dos poderes aqui mencionados. Parágrafo $1 .^{\circ}-$ $\mathrm{O}$ interventor terá, em cada Estado, os proventos, vantagens e prerrogativas que a legislação anterior do mesmo Estado confira ao seu presidente ou governador, cabendo-lhe exercer, em toda plenitude, não só o poder executivo como tambem o poder legislativo"

Esse mesmo decreto, art. 11, $\S 8 .^{\circ}$, estatuiu: "Dos actos dos interventores haverá recurso para o chefe do governo provisório" E o decreto n. 20.348, de 29 de agosto de 1931, art. 33, estabeleceu o processo desse recurso.

2 - Fundado nesses dispositivos, A. I. da S. recorre, para a autoridade competente, do ato pelo qual o então Interventor interino no Estado, pelo dec. n. 6.714, de 29 de setembro de 1934, transformou o cartório privativo dos Feitos da Fazenda, de que o recorrente era serventuário, em cartório do civel. Ouvido a respeito, o sr. Procurador Fiscal da Fazenda do Estado opinou pela restauração do statu quo ante, dado o seu convencimento de não haver a refórma correspondido a uma necessidade pública. Mas, o Consêlho Consultivo entendeu não ser cabivel o recurso, uma vez que 
não mais existe "chefe do governo provisório" A seu ver, "essa entidade desapareceu com a reentrada do país nos quadros da lei. E absurdo fôra pretender substituí-la, no dispositivo citado do decreto n. 19.398, pelo chefe legal da Nação. Importaria isso em outorgar ao Presidente da República, a quem se fez questão de não deixar a faculdade de promulgar decretos-leis no interregno da entrada em vigor da Lei Magna até a reunião do Legislativo Ordinário, o poder de legislar, revogando decretos emanados dos governos provisórios dos Estados, estes no exercício, ainda, de poderes discricionários"

3 - E' preciso não esquecer, todavia, que pela promulgação da nova Carta Constitucional da República, os interventores não perderam a sua qualidade de delegados do Govêrno Federal. Na monografia que escrevemos sobre "A Intervenção Federal nos Estados", á pag. 121 da 1. ${ }^{\mathrm{a}}$ edição (1926), e á pag. 207 da $2 .^{a}$ edição (1930), deixámos consignado este princípio: "Seja qual for a extensão dos poderes confiados ao interventor, serão eles sempre exercidos em nome e por autoridade do govêrno da União. Esse funcionário não representa o Estado, nem se identifica com o seu govêrno, porque nada mais faz, senão exercer funções federais, expressas e transitórias, de garantia e reconstrução do regimen local, alterado, ou subvertido" Essa é, aliás, a lição de Joaquin V González, (Manual de la Constitución Argentina, 11. a edição, p. 743) : "Sea cualquiera la extensión de facultades que el Presidente le acuerde, serán siempre ejercidas en nombre y por autoridad del Gobierno Federal" Não varia o conceito de Arturo M. Bas, (El Derecho Federal Argentino, 1/172): "El interventor no ejerce jurisdicción autorizada por la Provincia, sino la nacional, a nombre y por autorización del Gobierno Nacional" Subordinados ao poder federal, em cujo nome exercem funções constitucionais nos Estados, os interventores federais estão adstritos ás nórmas de ação, que lhes foram traçadas e ao poder federal devem contas dos atos que, nessa qualidade, praticaram. 
4 - Acresce notar que "a União é responsavel pelas perdas e danos oriundos de atos ilegais do interventor, enquanto durar a intervenção e persistirem os efeitos dos aludidos atos", (ERnesto Leme, op. cit., 2. ${ }^{a}$ edição, p. 208). Essa é a opinião de juristas do valor de Clovis Bevilaqua, Aquiles Bevilaqua, Eduardo Esplnola, J. X. Carvalho de MenDonça, Epitacio PessôA, (vêde Pandectas Brasileiras, 7/45360). Essa a jurisprudencia da Suprema Corte, (Revista de Direito, 82/126 e Revista de Jurisprudência Brasileira, 4/252 e 5/477). Fôra iníquo dar á União similhante responsabilidade, sem facultar, aos poderes federais, por meio de recursos dos interessados, ou conhecimento da hipotese, ex officio, revogar atos, atentatórios de direitos, praticados por seus delegados nos Estados.

5 - Aos interventores não cabe indagar se o Presidente da República poderá, ex propria auctoritate, revogar quaisquer decretos que, por força do disposto no art. $11, \S 1 .^{\circ}$, do decreto federal n. 19.398, de 11 de novembro de 1930 , hajam expedido. Dentro das nórmas constitucionais, que nos regem, o chefe do Poder Executivo saberá acautelar os interesses da Nação, corrigindo as injustiças que acaso tenhanı sido cometidas. E esse recurso é de ser encaminhado, maximé atendendo-se ao rigor do disposto no art. 31, do decreto federal n. 20.348, de 29 de agosto de 1931, que véda á justiça tomar conhecimento de quaisquer reclamações, contra os atos dos interventores, se deles não se interpôs recurso administrativo, nos prazos estipulados, ou se o mesmo não logrou provimento.

6 - Não nos cabe opinar sobre a conveniência ou inconveniência de se manter, na organização judiciária do Estado, um cartório privativo dos Feitos da Fazenda. O Govêrno do Estado, em sua alta sabedoria, decidirá a respeito.

Mas, não nos parece haver lesão aos direitos do serventuário respetivo, no decreto estadual n. 6.714, de 29 de setembro de 1934 . 
Não se privou, a esse funcionário, do cartório para o qual fôra nomeado. Não se lhe retirou a vitaliciedade que o garantia. A distribuição dos serviços da justiça é que sofreu, no interesse público, evidentemente, uma transformação.

A vitaliciedade, não ha duvida, assegura a permanência do funcionário no cargo. Mas, não póde privar o Estado do direito de reorganizar os serviços publicos, de sorte a lhes garantir uma eficiência maior.

7 - E' o que nos cabe opinar, sobre as teses jurídicas ventiladas no presente recurso. Da conveniência, ou inconveniência, da nova modificação, que se pleiteia, sómente o Governo, em seu esclarecido critério, é que poderá ajuizar.

São Paulo, 17 abril 1935. 